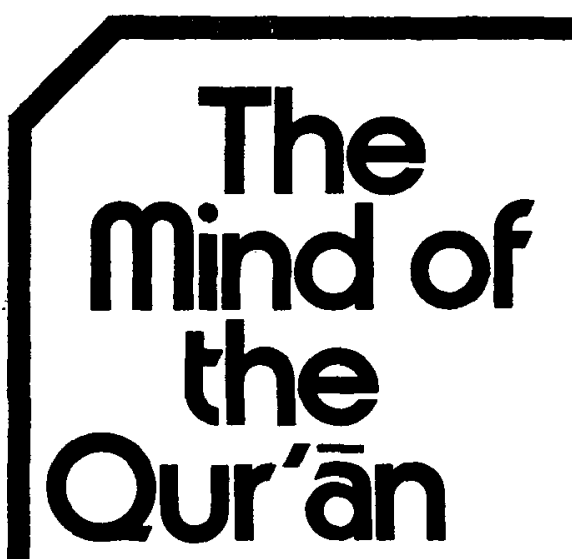

\section{KENNETH CRAGG}

Book and people have never been so surely joined as in Islam. The sense of final Scripture in possession has made the Muslim what he is for almost fourteen centuries of interpretation and acceptance. This book therefore inquires "How has the book been received by Islam ?”. It offers a deep and sympathetic study of the meaning of the Qur'ān in the life of Muslims. As a sequel to the author's The Event of the Qur'än (1 97I), it is concerned with the main thrust of original Islam, its traditions and its role in today's dialogue of religion and secular man.

$£ 4.25$

GEORGE ALLEN \& UNWIN
CANADIAN JOURNAL OF PHILOSOPHY

Published by the Canadian Association for Publishing in Philosophy

EDITORIAL BOARD John King-Farlow (Alberta), Kai Nielsen (Calgary), Terence Penelhum (Calgary), William Rozeboom (Alberta) La Redaction

\section{Volume II Number 3 March 1973}

Kierkegaard on 'Truth is Subjectivity' and 'The Leap of Faith'RICHARD SCHACHT Shooting, Killing and Dying -JÖNATHAN BENNETT

Salvation in Plato and

St. Paul: An Essay in Normative Ethics-

GEORGE NAKHNIKIAN

Hare et L'Universalization des Decisions Morales-

CLAUDE PANACCIO

The Criteria of Punishment: Some Neglected Considerations-

TZIPORAH KASACHKOFF None in ParticularJOHN WOODS

Comment on Locke-

G. J. WARNOCK

Critical Notice of T. Nagel, The Possibility of Altruism-

Critical Notice of

L. G. MILLER

F. E. Sparshott, Looking for Philosophy-R. W. HEPBURN

Annual Subscription--Institutions \$12; Individuals \$10; Students \$5Abonnement Annuel

Subscriptions to-Roger A. Shiner (Managing Editor)-pour Abonnements

Manuscripts to-Charles G. Morgan (Executive Secretary)-pour Manuscrits

Department of Philosophy, University of Alberta, Edmonton, Alberta, T6G 2E1, Canada 


\section{Libellus de Diversis Ordinibus}

\section{et Professionibus qui sunt in Aecclesia}

\section{Edited and translated by $G$. Constable and B. Smith}

The Libellus de diversis ordinibus should be of interest to students of medieval intellectual history and of medieval religious movements and spirituality. It was written in the thirties or forties of the twelfth century, probably in the diocese of Liège, and is a description of the similarities and differences among the various orders of monks, canons, and hermits of the time. Frontispiece $\mathbf{1 3 . 5 0}$ Oxford Medieval Texts

\section{Gnosis: A Selection of Gnostic Texts}

\section{Volume I: Patristic Evidence}

Edited by Werner Foerster

\section{English translation edited by R. McL. Wilson}

The present work provides a comprehensive selection of patristic texts for the study of Gnosticism, introduced and annotated by distinguished German scholars. A second volume will include extracts from the Nag Hammadi library and from

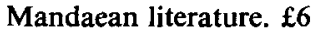

\section{A Catalogue of Manuscripts in Lambeth Palace Library}

MSS. 1222-1860

Compiled by E. G. W. Bill

In addition to many medieval manuscripts, this catalogue covers the church history of the last $\mathbf{4 0 0}$ years in England and Scotland, and includes important papers on America, Australia, South Africa, and Asia. There is also a considerable amount of political material, and papers about architecture, education, and local history. $£ 12 \cdot 50$

\section{The Figurae of Joachim of Fiore}

\section{Marjorie Reeves and Beatrice Hirsch-Reich}

The figurae of Joachim of Fiore are in many ways a unique expression of the medieval imagination, the work of an artist and mystic who endeavoured to express the mysteries of the Trinity and the patterns of history in rich and strange visual forms. This book attempts to trace this evolution and to unravel the complexities of their interpretation. 25 plates 10 text figures $£ 10$ Oxford Warburg Studies

\section{Church History in the Age of Science}

Historiographical Patterns in the United States 1876-1918

\section{Henry Warner Bowden}

f5 University of North Carolina Press

Oxford University Press 


\section{English Roman Catholics and Higher Education 1830-1903}

\section{Vincent Alan McClelland}

The effort to come to terms with the larger society within which Roman Catholics had to function is the main theme of this study. The problem can be seen in microcosm in the fight for higher education and in the internal tensions and turmoil to which it gave rise. $£ 7$

\section{Religion and Soviet Foreign Policy 1945-1970}

\section{William C. Fletcher}

This book evaluates the role that religious individuals and organizations have played in Soviet foreign affairs. The discussion encompasses the major religions and international religious bodies, and the study shows that religion, while never a dominant concern of Soviet foreign policy, has played and continues to play an increasingly pervasive role. $\mathfrak{£} \cdot 50$ Royal Institute of International Affairs

\section{Church and State in Ethiopia 1270-1527}

\section{Taddesse Tamrat}

This book reconstructs the history of Christian Ethiopia during the period when the state suddenly grew into an extensive empire, bringing under its control many pagan Falashe and Muslim peoples. From the rich historical records of medieval Ethiopia the author has been able to fill many gaps and to cover the history of the whole period as part of a single dynamic trend of development. Frontispiece $\$ 5 \cdot 50$ Oxford Studies in African Affairs

\section{The Orthodox Churches and the Secular State The Sir Douglas Robb Lectures 1970 \\ Steven Runciman}

Sir Steven Runciman surveys in these lectures the relationship of Church and rulers in the Byzantine Empire, Tsarist Russia, the Ottoman Empire, and their successor states, as a means of understanding how they face their problems today. f2 Auckland University Press

\section{God the Problem}

Gordon D. Kaufman

Mr Kaufman explores the question of why God is a problem for many moderns, the dimensions of that problem, and the inner logic of the notion of God as it has developed in Western culture. 15 Harvard University Press 


\section{Notes for CONTRIBUTORS}

I. Contributions and books for review should be sent to the editor, Professor H. D. Lewis, King's College, Strand, London, W.C.2. Books published in America should be sent to Professor J. E. Smith, Department of Philosophy, Yale University, New Haven.

2. Contributions should normally be in English and should preferably be typewritten (doublespaced on quarto paper). Contributors should keep a copy themselves for use when correcting proofs.

3. Submission of an article is taken to imply that it has not previously been published, or is not being considered for publication elsewhere. If rejected manuscripts are to be returned, stamps or international coupons should be sent to cover postage.

4. All contributors receive 50 free separates.

PRINTED BY Unwin Brothers Limited OLD WOKING SURREY ENGLAND 


\section{Religious Studies}

Volume 9, Number 1, March 1973

\section{CONTENTS}

ATTFIELD, ROBIN

The God of Religion and the God of Philosophy

KING, ROBERT H.

The Conceivability of God

WARD, KEITH

Explanation and Mystery in Religion

Austin, William H.

Religious Commitment and the Logical Status of Doctrines

MERCIER, ANDRÉ

Contemplation versus Reason. An Inquiry into Human Knowledge in the Light of Theory of Values

CAMPBELL, RICHARD

History and Bultmann's Structural Inconsistency

KRIEG, CARL E.

Bonhoeffer's Letters and Papers

Reviews

C. Cambridge University Press, 1973

\section{CAMBRIDGE UNIVERSITY PRESS}

Bentley House, 200 Euston Road, London NW1 2DB

American Branch: 32 East 57th Street, New York, N.Y. 10022

$£_{2.80}$ net $\$ 7.50$ in U.S.A. Subscription Price $£^{8.50}$ net $\$ 24.50$ in U.S.A. Religious Studies is indexed in the Index of Religious Periodical Literature 